\title{
Earth and Wind Industries Playing with Fire: The Concurrent Rights of Wind Farm Operators, Oil and Gas Developers, and Landowners in Kansas*
}

\section{INTRODUCTION}

Oil wells across the country have recently been confronted with a big, expensive neighbor that has sprung up almost overnight: wind farms. Wind power is currently the fastest growing alternative energy source in the world, ${ }^{1}$ but the "swiftness with which this renewable resource has been developed seems to have resulted in the law lagging behind the industry."2

The surface owner of rural land generally uses the surface for agricultural purposes, such as growing crops or grazing animals. The surface owner may also lease that land to wind farm operators to erect turbines that generate electrical energy and lease the same acreage to oil and gas producers to extract oil and natural gas. ${ }^{3}$ Wind farm operators and oil and gas producers simultaneously use the surface of the land where both are producing their respective products. Wind farms have a relatively small footprint, but require a large amount of land and unobstructed airflow. ${ }^{4}$ This creates the potential for conflicts between wind farm developers, oil and gas producers, and surface owners, such as when multiple parties want to use a particular location on the surface or

David R. Green. J.D. candidate 2014, University of Kansas School of Law; B.S. 2011, University of Kansas. I would especially like to thank Karl Hesse for his assistance and for introducing me to the issues addressed in this Comment. I would also like to thank the University of Kansas Law Review staff and board, Professor Uma Outka, and my parents for their help.

1. See Michael J. Stephan, Note, Wind Severance, 40 TEX. ENVTL. L.J. 73, 73 (2009) (citing Meredith Blaydes Lilley \& Jeremy Firestone, Wind Power, Wildlife, and the Migratory Bird Treaty Act: A Way Forward, 38 ENVTL. L. 1167, 1169 (2008); Nicholas H. Rabinowitsh, Bringing New Source Review Back: The Supreme Court's Surprise (and Disguised) Attack on Grandfathering Old Coal Plants in Environmental Defense v. Duke Energy Corp., 31 EnVIRONS ENVTL. L. \& POL'Y J. 251, 260 (2008)).

2. Id. at 75 .

3. See, e.g., Osage Nation ex rel. Osage Minerals Council v. Wind Capital Grp., LLC, No. 11CV-643-GKF-PJC, 2011 WL 6371384, at *8 (N.D. Okla. Dec. 20, 2011) (involving a dispute between the mineral estate owner and the wind developer).

4. Becky H. Diffen, Comment, Energy from Above and Below: Who Wins When a Wind Farm and Oil \& Gas Operations Conflict?, 3 TeX. J. OIL GAS \& ENERGY L. 240, 242 (2008). 
one party's use of the surface interferes with the development of another party's estate.

Kansas common law and the Kansas Statutes do not directly address how these conflicts are to be resolved, and Kansas does not necessarily follow the approaches used in other jurisdictions for resolving similar conflicts. ${ }^{5}$ But as the wind farm industry expands throughout Kansas and other parts of the United States, conflicts are inevitable, and the resolution of those conflicts in Kansas is up in the air, while states such as Oklahoma have already addressed the issue through case law and legislation. ${ }^{6}$ What approach will Kansas courts use to determine which party has superior surface rights between the various interest holders? How should developers and the Kansas Legislature approach these potential conflicts?

This Comment proposes that the rights of surface owners, wind farm operators, and oil and gas producers should be evaluated by applying Kansas case law on similar conflicts between landowners and lease holders, adapting solutions from other jurisdictions, and addressing public policy concerns. Part II discusses wind farm operations in general, the nature of wind farm and mineral estate leases, how conflicts between surface owners and oil and gas producers have been resolved in Kansas, and how similar conflicts have been resolved in Texas and Oklahoma. Part III examines how established contract law will affect potential conflicts between the various interest holders, how disputes between wind farm operators and oil and gas developers should be resolved in Kansas, and how public policy concerns affect these potential conflicts. Ultimately, this Comment proposes that Kansas courts and the Kansas Legislature should adopt a modified form of the accommodation doctrine used by Texas and Oklahoma, which would require wind farm developers, oil and gas producers, and surface owners to avoid creating conflicts with the prior, existing uses of the surface by other interest holders.

This Comment assumes that the wind farm operator has a lease with the surface owner to operate the wind farm, that the oil and gas producer is the owner of the mineral estate or has a lease with the mineral estate owner - who may or may not also be the surface owner-and that there is a conflict between the interest holders concerning use of the surface.

5. See Rostocil v. Phillips Petroleum Co., 502 P.2d 825, 826 (Kan. 1972) (maintaining that under Kansas law the mineral estate is not the dominant estate and the surface estate is not the servient estate).

6. E.g., Osage Nation, 2011 WL 6371385; OKLA. STAT. tit. 52, § 803 (Supp. 2013). 


\section{BACKGROUND}

\section{A. Characteristics and Requirements of Wind Farms}

Wind farms provide important economic and environmental benefits and have expanded rapidly in the United States over the last decade. Specifically, the development of wind power provides "economic development to rural regions, reduces water consumption in the electric power sector, and reduces greenhouse gas production by displacing fossil fuels." ${ }^{7}$ A single wind farm in Nevada, for instance, was estimated to provide electrical power for 45,000 homes, $\$ 3$ million in tax benefits to local schools, 225 temporary jobs, and an overall local benefit of \$45 million. ${ }^{8}$ Additionally, "Congress has articulated the public policy that our nation should incorporate clean energy as a necessary part of America's future and it is essential to securing our nation's energy independence and decreasing green house emissions."

As of late 2012, there were more than 45,000 wind turbines located in United States with a capacity exceeding 60 gigawatts (GW), which is enough to power 14.7 million American homes. ${ }^{10}$ That $60 \mathrm{GW}$ is equivalent to the electricity generated by fourteen nuclear power plants or fifty-two coal plants, avoids emitting 95.9 million tons of $\mathrm{CO}_{2}$, and represents an investment of $\$ 120$ billion. ${ }^{11}$ The growth of the wind energy industry is occurring rapidly; the total capacity was $4.1 \mathrm{GW}$ in 2001, 9.0 GW in 2005, 25.1 GW in 2008, and $40.3 \mathrm{GW}$ in $2010 .^{12}$ Approximately $8.4 \mathrm{GW}$ were installed in the fourth quarter of 2012 alone, with $13.1 \mathrm{GW}$ installed in all of 2012. ${ }^{13}$

Wind energy developers use computer models to estimate the amount of energy a wind turbine will generate based on the terrain, nearby infrastructure, and wind flow. ${ }^{14}$ These computer models are also

7. NAT'L RENEWABle ENERgy LaB., U.S. DEP'T OF ENERGY, ECONOMIC BENEFITS, CARBON DIOXIDE (CO2) EMISSIONS REDUCTIONS, AND WATER CONSERVATION BENEFITS FROM 1,000 MegawatTs (MW) OF New WIND POWER IN KANSAS 1 (June 2008), http://www.windpower ingamerica.gov/pdfs/economic_development/2008/ks_wind_benefits_factsheet.pdf.

8. W. Watersheds Project v. Bureau of Land Mgmt., 774 F. Supp. 2d 1089, 1091 (D. Nev. 2011).

9. Id. at 1103.

10. AM. Wind Energy Ass'N, AWEA U.S. Wind Industry Fourth QUARTer 2012 MARKET REPORT 3 (Jan. 30, 2012), http://www.awea.org/learnabout/publications/reports/upload/ AWEA-Fourth-Quarter-Wind-Energy-Industry-Market-Report_Executive-Summary.pdf.

11. Id. at 4.

12. Id. at 5 .

13. Id. at 6 .

14. Diffen, supra note 4, at 244. 
used to place the wind turbines for optimal output. ${ }^{15}$ Wind turbines must be spread out over a large amount of land to reduce turbulence and be optimally placed to maximize the amount of electricity generated, which also generally requires "non-obstruction easements for at least one mile upwind of all turbines" to maximize the efficiency of wind flow to the turbines. $^{16}$ Non-obstruction easements prohibit tall objects, such as buildings, from being located within a certain distance or area upwind of the turbine. ${ }^{17}$

These non-obstruction requirements create the potential for numerous conflicts with oil and gas producers. The wind farm operator might want to place a turbine in a specific location and spend large amounts of money during planning phases to optimize the energy production of the turbine based on that location; meanwhile, the oil and gas producer might spend large amounts of money locating a significant oil deposit and place a well in that same location or nearby. In another scenario, the wind turbine might already be in construction, and the oil and gas producer might want to place a well or other infrastructure in a location that would obstruct the wind flow to the turbine. Even small changes in airflow can reduce electrical output and significantly reduce the economic viability of a particular wind energy development. ${ }^{18}$ The potential conflicts are endless.

\section{B. Wind Farms in Kansas}

Wind farms are especially significant in Kansas, which has the second highest estimated annual potential for generating electricity via wind power of any state, behind only Texas. ${ }^{19}$ While Kansas has a current capacity around only $2.8 \mathrm{GW}$, the ninth highest electrical capacity of any state, Kansas installed 1.4 GW of that total in 2012, which was the third most for the year, behind only Texas and

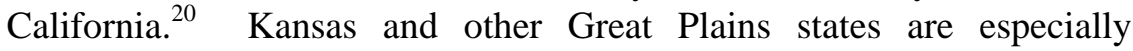
significant for utilizing wind energy because "very little of the land area is excluded due to insufficient resource[s]... or environmental

15. Id. at $244-45$.

16. Id. at 242 .

17. Id.

18. Id. at 245 .

19. ANTHONy Lopez et AL., NAT'L RENEWABle ENERgy LaB., U.S. RENEWABle ENERgy TECHNICAL ANALYSIS: A GIS-BASED ANALYSIS 14 (July 2012), http://www.nrel.gov/docs/fy12osti/ 51946.pdf.

20. AM. Wind ENERGY Ass'N, supra note 10, at 3-7. 
exclusions."21 The relatively high wind speeds in Kansas also make the state a more desirable location for wind farms; the average annual wind speed is about thirty feet per second at 260 feet above the ground in most of Kansas, whereas the average annual wind speed is around only sixteen feet per second at 260 feet above the ground on the east and west coasts. $^{22}$

Kansas alone could theoretically generate an estimated 3,101,576 gigawatt-hours (GWh) of wind energy annually, Texas could generate an estimated 5,552,400 GWh, and the United States as a whole could generate an estimated 32,784,004 GWh. ${ }^{23}$ These theoretical GWh estimates do not consider economic or market factors, which could severely limit the actual production of each state. ${ }^{24}$ For reference, the United States only consumed 3,889,000 GWh in 2010. ${ }^{25}$ While Kansas wind farms will probably never provide $80 \%$ of the electricity needed in the United States, these statistics show the importance and potential for expansion of the wind industry in Kansas.

It is estimated that the development of $1 \mathrm{GW}$, or 1,000 megawatts (MW), of wind power in Kansas provides an overall economic benefit of $\$ 1.08$ billion, annual $\mathrm{CO}_{2}$ reductions of 3.2 million tons, and annual water savings of 1,816 million gallons. ${ }^{26}$ An estimated \$188.5 million would go directly to local economies during the construction of the wind turbines, while another $\$ 137.5$ million would go to local economies indirectly during the construction phase through banks, equipment suppliers, manufacturers, restaurants, retail businesses, and other local organizations. ${ }^{27}$ Additionally, $1 \mathrm{GW}$ of new wind development creates 3,168 temporary jobs during construction and 432 long-term jobs. ${ }^{28}$

Wind electricity generation is increasing more rapidly in Kansas than in many other states. From 2001 to 2007, the production of wind energy in Kansas increased by 2,793.5\%, eighth highest in the country, and the

1. LOPEZ ET AL., supra note 19, at 8.

22. See U.S. ENERgy Info. AdMin., U.S. DEP'T OF ENERGy, ANNUAL ENERGy REVIEW 2011, at 110 (Sept. 2012), http://www.eia.gov/totalenergy/data/annual/pdf/aer.pdf (providing a geographical map of wind speed data throughout the United States).

23. LOPEZ ET AL., supra note 19, at 14.

24. Id. at iv.

25. Cent. InTElligence Agency, The World FACTBOOK: North AMERICA: THE United STATES: ENERGY, https://www.cia.gov/library/publications/the-world-factbook/geos/us.html (last visited Mar. 13, 2013).

26. NAT'L RENEWABLE ENERGY LAB., supra note 7, at 1.

27. Id.

28. Id. 
wind-generated electrical capacity in Kansas doubled in 2012. ${ }^{29}$ As of the end of 2012, BP Wind Energy is building the state's largest wind farm in Harper, Barber, and Kingman counties of southern Kansas. ${ }^{30}$ The wind farm will consist of 300 turbines spread over 66,000 acres and will be able to power around 125,000 homes. ${ }^{31}$ The various landowners will receive \$2 million per year from BP, while the three counties will collectively receive $\$ 1.2$ million annually for an estimated twenty-five years. $^{32}$

And "[r]ight next to those wind turbines sits an oil well"; oil companies are just beginning the process of extracting billions of barrels of oil from the Mississippian limestone formation located in southern Kansas. $^{33}$ Oil industry activity in that region could last over twenty years, and notable oil and gas producers, including SandRidge Energy, Chesapeake Energy, and Shell, as well as local companies, are involved in the project. $^{34}$ Although it is fairly early in the process for realistic economic estimates, SandRidge Energy alone plans to spend $\$ 700$ million in Kansas in 2013 and early 2014. ${ }^{35}$

These simultaneous industry booms have not gone off without a hitch. The rapid expansion of the wind and oil industries has already caused a housing shortage in the area, increased traffic, worn down local roads, and caused an increase in traffic accidents and DUIs. ${ }^{36}$ These two industries are on a collision course in Kansas, and it is only a matter of time before a lawsuit occurs with little guidance to resolve disputes.

29. Elizabeth Doris et al., NAT’L Renewable Energy Lab., State of the States 2009: Renewable ENERgy DeVelopment AND the ROLE OF POLICY 39 (Oct. 2009), http://www.nrel.gov/docs/fy10osti/46667.pdf; AM. WIND ENERGY Ass'N, supra note 10, at 3-7.

30. Blake Ellis, Wind: Kansas’ Other Energy Boom, CNN MoneY (June 6, 2012, 5:21 AM), http://money.cnn.com/2012/06/06/pf/kansas-wind-energy-america-boomtown/index.htm.

31. Id.

32. Id.

33. Id.

34. Kan. DeP'T of Commerce, Kansas Oil and Gas Activity IN the MississipPian Lime PLAY 1, available at http://www.kansascommerce.com/DocumentCenter/Home/View/1058 (last visited Mar. 13, 2013).

35. Id.; Daniel McCoy, Kansas Waiting for Mississippian Oil and Gas Potential to Become Clear, WiCHITA BUS. J., Nov. 27, 2012, http://www.bizjournals.com/wichita/blog/2012/11/kansaswaiting-for-mississippian-oil.html.

36. Ellis, supra note 30. 


\section{Relationships Between the Surface Owner, Mineral Estate Developer, and the Wind Farm Operator}

\section{Typical Factual Background}

Before exploring the potential conflicts and resolution of disputes between the various interest holders, it is important to understand the relationships between the surface owner, the mineral estate developer, and the wind farm operator in general. The fee simple landowner owns the greatest possible real property estate. The fee simple landowner owns the surface property, the space above the surface, and the "underlying minerals and the right to explore for and produce" those minerals. ${ }^{37}$ The surface owner may sever the mineral estate from the surface estate and grant ownership of the mineral estate to another party. $^{38}$ The mineral estate owner has the right, either expressly or impliedly from the conveyance, to use as much of the surface as is reasonably necessary to explore and develop the mineral estate. ${ }^{39}$ The mineral estate owner - which might also be the landowner if the mineral estate is not severed from the surface estate-typically leases the right to explore and produce the mineral estate to an oil and gas developer. ${ }^{40}$

At the same time, landowners all over the country have executed wind leases with wind farm operators, granting the right to place wind turbines and other equipment on their land to harness wind energy. ${ }^{41} \mathrm{~A}$ wind lease inherently and necessarily contains, either expressly or impliedly, the right to use the surface as is reasonably necessary to develop the wind farm. Otherwise, the wind lease would be useless. Although courts and legal academics have discussed the severability of the wind estate from the surface, ${ }^{42}$ severing the wind estate is not yet a common practice and this Comment does not address it. Thus, all three interest holders - the surface owner, the mineral estate owner or lessee, and the wind farm lessee-have concurrent rights to use the surface property and can potentially interfere with each other's uses, leading to

37. J. Michael Morgan \& Glen Droegemueller, Accommodation Between Surface Development and Oil and Gas Drilling, 24 CoLO. LAW. 1323, 1323 (1995).

38. Id.

39. Id.

40. Id.

41. See Stephan, supra note 1, at 76.

42. See, e.g., Contra Costa Water Dist. v. Vaquero Farms, Inc., 58 Cal. App. 4th 883 (1997); Stephan, supra note 1 at $75-76$. 
disputes and litigation. ${ }^{43}$ But how should it be determined who has priority or superior rights to the surface?

2. Implied Covenants of Reasonable Development and Reasonable Use of the Surface

Implied covenants are "inferred from the whole agreement and conduct of the parties," as opposed to express covenants, which are created by the words of the parties. ${ }^{44}$ Implied covenants can be overcome only "by express language showing a contrary intent.",45 A duty of good faith and fair dealing is implied in every contract, which requires that the parties do not "intentionally and purposely do anything to prevent the other party from carrying out his part of the agreement, or do anything which will have the effect of destroying or injuring the right of the other party to receive the fruits of the contract."46

Unless a lease expressly provides otherwise, oil and gas leases contain an implied covenant of reasonable development-also known as the "prudent-operator" rule-requiring the mineral lessee to explore and develop the land as "an operator of ordinary prudence" would under the same or similar circumstances, considering the interests of both lessee and lessor. ${ }^{47}$ Implied covenants of oil and gas leases do not require the mineral lessee to engage in unprofitable endeavors, even if the exercise would be beneficial or profitable to the lessor. ${ }^{48}$ "It is only to the end of mutual benefit or profit to both lessor and lessee that reasonable diligence is required." 49

Oil and gas leases also contain an implied covenant of reasonable use of the surface to develop the land allowing the lessee of the oil and gas lease to use the surface reasonably to perform the object of the lease. ${ }^{50}$ However, this covenant does not allow the oil and gas lessee unlimited use and discretion regarding the surface estate. ${ }^{51}$ For example, when

\footnotetext{
43. See, e.g., Osage Nation ex rel. Osage Minerals Council v. Wind Capital Grp., LLC, No. 11CV-643-GKF-PJC, 2011 WL 6371384, at *8 (N.D. Okla. Dec. 20, 2011).

44. BLACK's LAW DiCTIONARY 419 (9th ed. 2009).

45. Farrar v. Mobil Oil Corp., 234 P.3d 19, 29 (Kan. Ct. App. 2010).

46. Daniels v. Army Nat’l Bank, 822 P.2d 39, 42 (Kan. 1991) (citing Bonanza, Inc. v. McLean, 747 P.2d 792, 801 (Kan. 1987)).

47. Fischer v. Magnolia Petroleum Co., 133 P.2d 95, 99 (Kan. 1943).

48. Id. at 100 .

49. Id.

50. Mai v. Youtsey, 646 P.2d 475, 479-80 (Kan. 1982).

51. See Thurner v. Kaufman, 699 P.2d 435, 439 (Kan. 1985) (explaining that a lessee may not "overreach" or exercise its rights in a way that would harm the lessor's pursuits).
} 
surface use by the mineral lessee injures or interferes with the lessor's agricultural pursuits, liability may be imposed in the absence of an express provision in the contract. ${ }^{52}$

\section{Analyzing Leases and Easements in Kansas}

Although referred to as an oil and gas lease, the conveyance functions as a lease of the mineral estate and as an easement of the surface property, whereas the wind lease may be a lease or easement simultaneously. ${ }^{53}$ A lease transfers exclusive possession and control of the property to the tenant, or lessee, and grants a reversion to the landlord, or lessor. ${ }^{54}$ But merely calling an agreement a lease does not create a lease or a landlord-tenant relationship. ${ }^{55}$ An easement is a permanent interest in real property, as opposed to a personal interest revocable at the will of the landowner, which ordinarily involves "the privilege of doing or not doing a certain class of act on or in connection with another's land." 56 As used in this context, "permanent” means for a distinct duration of time, instead of forever or infinitely. ${ }^{57}$ The primary types of easements are:

(1) [A] right-of-way, (2) a right of entry for any purpose relating to the dominant estate, (3) a right to the support of land and buildings, (4) a right of light and air, (5) a right to water, (6) a right to do some act that would otherwise amount to a nuisance, and (7) a right to place or keep something on the servient estate. ${ }^{58}$

In Kansas, the holder of an easement on real property is generally the "dominant tenant" and the landowner is the "servient tenant."59 The servient tenant may use the land covered by the easement in any manner that does not unreasonably interfere with the dominant tenant's use of the easement. $^{60}$ An obstruction or disturbance by the servient tenant is not

\footnotetext{
52. Id.

53. Shannon L. Ferrell, The Technical and Ethical Challenges for Lawyers in Evaluating Wind Energy Development Agreements, 17 DrAKE J. AGRIC. L. 55, 60 (2012).

54. In re Am. Legion Post No. 81, 255 P.3d 31, 33 (Kan. Ct. App. 2011).

55. James W. Ely \& Jon W. BRUCE, The LaW of Easements \& LiCenses in Land § 11.1 (2012).

56. Gilman v. Blocks, 235 P.3d 503, 510 (Kan. Ct. App. 2010) (citing Stanolind Pipe Line Co. v. Ellis, 45 P.2d 846, 848 (Kan. 1935)).

57. Isley v. City of Wichita, 174 P.3d 919, 923 (Kan. Ct. App. 2008).

58. BLACK's LAW DiCTIONARY 586 (9th ed. 2009).

59. Potter v. N. Natural Gas Co., 441 P.2d 802, 805 (Kan. 1968).

60. Gilman, 235 P.3d at 514.
} 
actionable unless the obstruction or disturbance materially interferes with the dominant tenant's reasonable enjoyment of the easement. ${ }^{61}$

When the mineral estate is severed from the surface estate, two separate estates exist, each with "separate and distinct titles in severalty." ${ }^{2}$ The owner of the severed mineral estate gains an easement implied by necessity, which gives the mineral estate owner the implied right to enter the overlying surface to reasonably explore and develop the mineral estate. ${ }^{63}$ Under easements implied by necessity, whatever is necessary for the beneficial use and enjoyment of the property is conveyed along with the property itself. ${ }^{64}$ Easements implied by necessity exist when (1) a common owner severs property and (2) the easement is strictly necessary for the use and enjoyment of the property at the time of severance. ${ }^{65}$

An oil and gas lease thus creates an interest in two distinct estates: a lease of the mineral estate and an easement on the surface property. An oil and gas lease creates a lease of the mineral estate, but functions as merely an easement on the surface property. The oil and gas lease is a lease of the mineral estate because it transfers the exclusive possession and control of the mineral estate to the oil and gas lessee and grants a reversion based on specified terms to the owner of the mineral estate. ${ }^{66}$

The oil and gas lease does not create a lease with respect to the surface property because the oil and gas lessee, the landowner, and other parties, such as wind farm developers, share possession and control of the surface property. Merely labeling the oil and gas lease as such does not create a lease of the surface property. ${ }^{67}$ This quasi-easement interest in the surface property is created either expressly by the terms of the contract conveying the oil and gas lease or impliedly by the implied right to make reasonable use of the surface.

Regardless of how the interest in the surface property is created, the oil and gas lease functions as, and resembles, an easement of the surface estate. The oil and gas lessee has an implied right-of-way of ingress and egress on the property. ${ }^{68}$ The lessee also inherently has a right to do acts that would otherwise amount to a nuisance, such as making noise when

\footnotetext{
61. Mid-Am. Pipeline Co. v. Wietharn, 787 P.2d 716, 720 (Kan. 1990).

62. J.R. Crowe Coal \& Mining Co. v. Atkinson, 116 P. 499, 500 (Kan. 1911).

63. Mai v. Youtsey, 646 P.2d 475, 479-80 (Kan. 1982).

64. Smith v. Harris, 311 P.2d 325, 334 (Kan. 1957).

65. Id. at 334-35.

66. In re Am. Legion Post No. 81, 255 P.3d 31, 33 (Kan. Ct. App. 2011).

67. ELY \& BRUCE, supra note 55, § 11.1.

68. See Mai, 311 P.2d at 480 (discussing the rights of ingress and egress).
} 
drilling wells, and an implied right to place and keep equipment required for the development and production of oil and gas on the surface estate under the implied covenant to make reasonable use of the surface. ${ }^{69}$ These functions all strongly resemble the primary types of easements. ${ }^{70}$

A wind lease also resembles an easement of the surface property. Wind farm operators share possession and control of the surface estate with the surface owner and the oil and gas lessee, and exclusive control of the estate is typically required to create a lease. ${ }^{71}$ Lease conflicts generally address landlord-tenant relationships and determine the rightful lessee based on notice and the recording acts. ${ }^{72}$ The common law of leases, however, does not resolve the potential issues between wind farm developers, oil and gas producers, and surface owners because leases inherently and logically do not involve concurrent rights. Therefore, the oil and gas lease and the wind lease should be analyzed using well-established easement law, even though the conveyances are labeled leases.

\section{Specific and Blanket Easements in Kansas}

The respective rights of the surface owner, the oil and gas developer, and the wind farm operator also depend on whether the oil and gas developer and the wind farm operator have specific easements or blanket easements. An easement holder, generally the dominant tenant under Kansas law, may have a "specific easement" or a "blanket easement.,"73 A specific easement exists "where the width, length and location of an easement ... have been expressly set forth in the instrument.," ${ }^{, 74}$ In the case of a specific easement, "[t]he expressed terms of the grant or reservation are controlling... and considerations of what may be necessary or reasonable to a present use of the dominant estate are not controlling." ${ }^{75}$ In Aladdin Petroleum Corp. v. Gold Crown Properties, Inc., the landowner granted a specific easement for ingress and egress to an adjacent property over a definite width, length, and location. ${ }^{76}$ The

\footnotetext{
69. See id. at 479-80 (discussing the right of reasonable use of the surface).

70. See BLACK's LAW DICTIONARY 586 (9th ed. 2009) (listing the primary easements).

71. See Am. Legion, 255 P.3d at 33.

72. See id. (discussing the landlord-tenant relationship and stating that the "hallmark of a lease [is] the lessee's right to exclusive possession of the real property with a reversion to the lessor only at the end of the stated term”).

73. See Aladdin Petroleum Corp. v. Gold Crown Props., Inc., 561 P.2d 818, 822 (Kan. 1977).

74. Id.

75. Id.

76. Id.
} 
landowner then constructed carports over the easement, which "impair[ed] and interfere[d] with the privilege of passage" granted by the easement. $^{77}$ The Kansas Supreme Court held that the holder of the specific easement was "entitled to have the carports removed."78

Easements granted without specific dimensions are known as blanket easements. $^{79}$ A blanket easement exists where "the width, length and location of an easement... are not fixed by the terms of the grant or reservation [and] the dominant estate is ordinarily entitled to a way of such width, length and location as is sufficient to afford necessary or reasonable" use of the easement. ${ }^{80}$ The rights granted by a "blanket easement are less precise and not as readily enforceable as the" rights granted by a specific easement. ${ }^{81}$ Encroachment of a blanket easement must materially interfere with the reasonable enjoyment of the easement. $^{82}$

In Southern Star Central Gas Pipeline, Inc. v. Cunning, the landowner granted a blanket easement to a gas company to operate and maintain a pipeline. ${ }^{83}$ The landowner constructed a garage adjacent to the pipeline, with a horizontal clearance of forty-one inches between the garage and the pipeline. ${ }^{84}$ The gas company's policy was that a clearance of thirty-three feet on either side of the pipeline was necessary for maintenance, but this information was not included in the conveyance. $^{85}$ The court found that the garage did not unreasonably interfere with the maintenance of the easement and that the encroachment was slight compared to the $\$ 20,000$ cost required to move the garage. ${ }^{86}$

In Brown v. ConocoPhillips Pipeline Co., another blanket easement case, a tree located near a gas pipeline impaired ConocoPhillips's ability to inspect the pipeline and had the potential to damage the pipeline. ${ }^{87}$ The tree was a material interference with the ability to maintain the pipeline, and the court required the landowner to remove the tree. ${ }^{88}$ In

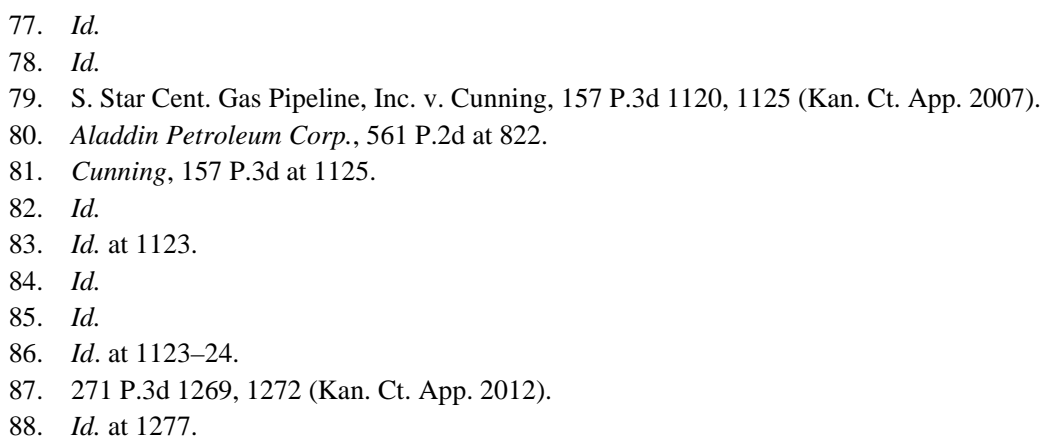


Cunning, "evidence was presented on both sides... [on] whether the garage caused a material impediment to the dominant tenant's easement by making excavation of the pipeline unreasonably difficult or impossible." 89 The evidence in Brown that the tree roots could harm the pipeline was undisputed by the parties. ${ }^{90}$

When the conveyance specifies the definite width, length, and location of the property subject to the easement, the easement holder is entitled to use that portion of the land as designated by the conveyance, and the surface owner and other interest holders cannot materially interfere with that portion of the property. ${ }^{91}$ Furthermore, the order in which specific easements are created may establish priority because a party cannot contractually "create in others a privilege which he did not have." 92 Thus, once the landowner grants a specific easement, she no longer has the privilege to use that land at her discretion and must defer to the dominant tenant. And because the landowner does not have a right to that land, she cannot grant exclusive or dominant rights to use that land in a subsequent lease or easement.

An oil and gas lessee obtains an easement over the surface, and if a specific area of the surface is not set forth, then those rights are a blanket easement. ${ }^{93}$ Wind farm operators, then, may have an advantage in priority because the nature of their business requires prior planning on location of equipment. Kansas law even dictates that instruments that create a wind farm lease or easement must contain "a description of the vertical and horizontal angles, expressed in degrees, and distances from the site of the wind... power system in which an obstruction to the wind... system is prohibited or limited...."94 If the conveyance contains the location of the wind turbines or reserves locations for other equipment, then the instrument is tantamount to a specific easement, with which the surface owner and other interest holders may not materially interfere. At the very least, recording a development plan that contains the location of turbines, lines, and other equipment may position the wind farm operator for priority over the blanket rights of the oil and gas producer.

89. Id. at 1275 .

90. Id.

91. See Smith v. Harris, 311 P.2d 325, 336 (Kan. 1957) (discussing the requirement that the interference by another interest holder be material).

92. Brooks v. Mull, 78 P.2d 879, 883 (Kan. 1938).

93. See supra Part II.C.3-4.

94. KAN. STAT. ANN. § 58-2272 (Supp. 2012). 


\section{The Kansas Wind Farm Statute}

Legal instruments that create a wind farm lease or easement must contain "a description of the vertical and horizontal angles, expressed in degrees, and distances from the site of the wind... power system in which an obstruction to the wind . . system is prohibited or limited."95 Non-obstruct clauses or easements restricting the placement of trees or structures on the property are often included in the wind lease. ${ }^{96}$

The Kansas Wind Farm statute, section 58-2272 of the Kansas Statutes, requires the instrument to contain the amount of space covered by the easement, but it does not require the instrument to contain the locations of the turbines or other equipment. ${ }^{97}$ If the conveyance contains the location of the wind farm equipment as well as the angles and distances from the system in which obstructions are prohibited, then the instrument creates a specific easement. Therefore, the surface owner and other interest holders cannot materially interfere with that portion of the property.

If the instrument does not contain the locations of turbines and other equipment, however, then the instrument creates a blanket easement. The surface owner and other interest holders may use any portion of the property that does not deprive the easement holder of the reasonable enjoyment of the easement. In other words, if the wind farm lessee could still place turbines on other portions of the property and make a profit, then the surface owner or other interest holders could reserve that designated location.

\section{Resolution in Other Jurisdictions}

1. The Texas Approach: The Accommodation Doctrine

In Texas and numerous other jurisdictions-but not necessarily in Kansas - the mineral estate is the dominant estate over the servient surface estate. $^{98}$ In a dominant-servient estate relationship, the mineral

95. Id.

96. Brent Stahl et al., Wind Energy Laws and Incentives: A Survey of Selected State Rules, 49 WASHBURN L.J. 99, 112 (2009).

97. KAN. STAT. ANN. § 58-2272.

98. Getty Oil Co. v. Jones, 470 S.W.2d 618, 621 (Tex. 1971); see also Rostocil v. Phillips Petroleum Co., 502 P.2d 825, 826 (Kan. 1972) (stating that the mineral estate lessee "does not own a dominant easement”); RICK D. DAVIS, JR., ACCOMMODATION DOCTRINE 2-3 (2006) (discussing the dominance of the mineral estate in five states). 
estate owner has the implied right to reasonably use the surface to develop the mineral estate. ${ }^{99}$ Essentially, ownership of the mineral estate is useless without the ability to access the mineral estate by way of the surface estate, and Texas has a strong public policy interest in "protecting and fostering the development of energy sources which benefit everyone." 100

The accommodation doctrine, or the alternative means doctrine, provides that if (1) there is an existing use by the surface owner that would be substantially impaired and (2) there is an alternative industry practice available to produce the minerals, "the rules of reasonable usage of the surface may require" the mineral estate owner to use the available alternative. $^{101}$ If there is no reasonable alternative available, then the mineral estate owner may interfere with the surface owner's use of the property "regardless of the [resulting] surface damage."

For example, in the Texas Supreme Court case Getty Oil Co. v. Jones, the surface owner installed an irrigation system that could pass over obstructions less than seven-feet tall, but after installation, the oil and gas lessee installed two pumps exceeding seven feet that interfered with the irrigation system. ${ }^{103}$ Other oil and gas producers in the area had lowered pumps into cellars to avoid the irrigation system. ${ }^{104}$ The taller pumps significantly impaired the existing use of the irrigation system, and the accommodation doctrine required the oil and gas producer to use available reasonable alternatives to avoid the conflict. ${ }^{105}$ The case was remanded to the trial court to determine whether the oil and gas lessee could actually lower the pumps in cellars and whether any other alternatives existed to avoid the conflict. ${ }^{106}$

In contrast, in Sun Oil Co. v. Whitaker, another Texas Supreme Court case, production from oil wells began to decrease, causing the mineral lessee to pump 100,000 gallons of fresh water into the oil wells each day to raise the pressure in the wells and increase oil production. ${ }^{107}$ The

\footnotetext{
99. Moser v. U.S. Steel Corp., 676 S.W.2d 99, 103 (Tex. 1984).

100. Diffen, supra note 4, at 243.

101. Haupt, Inc. v. Tarrant Cnty. Water Control \& Improvement Dist. No. One, 870 S.W.2d 350, 353 (Tex. Ct. App. 1994) (emphasis added); Diffen, supra note 4, at 246.

102. Haupt, 870 S.W.2d at 353 (quoting Tarrant Cnty. Water Control \& Improvement Dist. No. One v. Haupt, Inc., 854 S.W.2d 909, 911-12 (Tex. 1993)).

103. 470 S.W.2d 618, 620 (Tex. 1971).

104. Id.

105. Id. at $622-23$.

106. Id. at 623 .

107. 483 S.W.2d 808, 809 (Tex. 1972).
} 
surface owner sought damages from the mineral lessee for water it took without compensation and damage it caused to crops. ${ }^{108}$ Based on the accommodation doctrine, the mineral lessee had the right to use the water, which was part of the surface estate, "to the extent reasonably necessary for the development and production of such minerals." 109 No other alternative source of water was available to develop the mineral estate, and the court denied the surface owner's request for damages because to hold otherwise would have been "in derogation of the dominant estate." ${ }^{\prime 10}$

Directional drilling, also known as slant or nonvertical drilling, is increasingly a reasonable alternative to vertical drilling to produce oil and natural gas, and it greatly expands the mineral estate owner's flexibility in placing equipment to develop the mineral estate. ${ }^{111}$ With recent advances in drilling technology, directional drilling is becoming "more efficient and economically viable" compared to the simpler and less expensive vertical drilling. ${ }^{112}$ Directional drilling uses angles directed to specific oil reserves and allows extraction of oil and natural gas from areas unreachable using vertical drilling, such as under lakes. ${ }^{113}$ Additionally, directional drilling can minimize the surface footprint of drilling operations by allowing access to multiple wells from one centralized surface location. ${ }^{114}$ In Texas Genco, LP v. Valence Operating Co., the Texas Court of Appeals became the first Texas court to find that directional drilling was a reasonable alternative to straight-hole drilling even though directional drilling was more expensive. ${ }^{115}$

In summary, under Texas's accommodation doctrine, if the landowner, wind farm operator, or other interest holder has been using the surface and the actions of the dominant tenant would impair that use of the surface, then the dominant tenant must use any reasonably available alternative industry practice, such as directional drilling, to

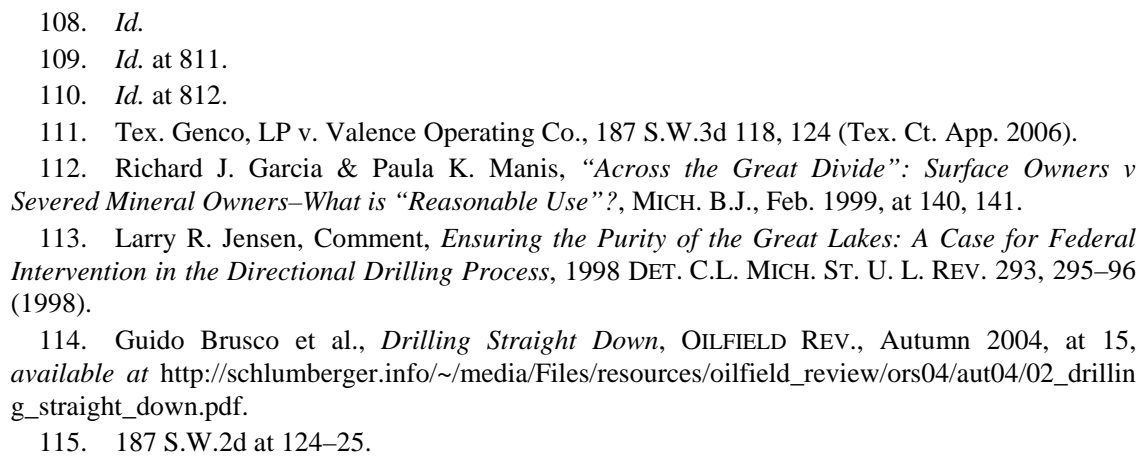

114. Guido Brusco et al., Drilling Straight Down, Oilfield Rev., Autumn 2004, at 15, available at http://schlumberger.info/ /media/Files/resources/oilfield_review/ors04/aut04/02_drillin g_straight_down.pdf.

115. 187 S.W.2d at $124-25$. 
develop the estate. With the increasing feasibility of directional drilling, it is becoming less likely that oil and gas developers would lack any reasonable alternatives to avoid a surface conflict by moving to a different, unused location on the surface. But if no such alternatives existed, the oil and gas developer, as the dominant estate owner, would be permitted to interfere with the existing surface use. ${ }^{116}$

\section{Oklahoma}

In the Northern District of Oklahoma case Osage Nation ex rel. Osage Minerals Council v. Wind Capital Group, LLC, the defendants, Wind Capital Group and Osage Wind, leased roughly 8,500 acres from seven surface owners in Oklahoma to construct a wind energy facility consisting of ninety-four turbines, underground collection lines, an overhead transmission line, two meteorological towers, and access roads. ${ }^{117}$ The actual footprint of the facility was less than $1.5 \%$ of the 8,500 acres, or approximately 120 acres. $^{118}$ Four different energy companies, all of which leased the mineral estate from the Osage Nation, also used the 8,500 acres for grazing livestock and for oil and gas production. ${ }^{119}$ The mineral estate had been severed from the surface estate in 1906 by the United States government and retained by the Osage Nation, a federally recognized Indian Tribe. ${ }^{120}$

The Osage Nation sought an injunction against the wind farm and claimed that the wind farm facilities unlawfully interfered with their "right to use so much of the surface of the land within the Osage Mineral Estate as may be reasonable for oil and gas development... including the right of ingress and egress therefor, for the purpose of exploring, severing, capturing and producing the oil and gas."121 Basically, the Osage Tribe thought a conflict would occur if one of the oil and gas lessees, Orion Exploration, wanted to drill an oil well at the same time and in the same location as wind turbine construction. ${ }^{122}$ Ultimately, the court found that the conflict was too "speculative and insufficient to

\footnotetext{
116. See Garcia \& Manis, supra note 112, at 141 (discussing the increasing availability of directional drilling); see also Haupt, Inc. v. Tarrant Cnty. Water Control \& Improvement Dist. No. One, 870 S.W.2d 350, 353 (Tex. Ct. App. 1994) (discussing the accommodation doctrine in Texas).

117. No. 11-CV-643-GFK-PJC, 2011 WL 6371384, at*1 (N.D. Okla. Dec. 20, 2011).

118. Id.

119. Id.

120. Id.

121. Id. at $* 2$.

122. Id. at *3.
} 
establish that the Wind Farm will interfere with development of the Osage Mineral Estate.”123

Additionally, and importantly, the court stated that if an actual conflict occurred, it "should be resolved by the parties in accordance with their respective obligations under federal and state law."124 In Oklahoma, as in Texas, the mineral estate is dominant over the servient surface estate. ${ }^{125}$ Furthermore, the District Court stated that if the wind farm operator could not comply with a request by the oil and gas lessee, then the oil and gas lessee could work around the conflict by using directional drilling or changing the location of the oil wells. ${ }^{126}$ If a specific, existing conflict could not be resolved in that manner, the lessee could seek redress in court. ${ }^{127}$

The court also found that the wind farm developers stood to lose over \$200 million in profits, previous expenditures, and contractual obligations if the court were to grant an injunction against the wind farm. ${ }^{128}$ Also, the state of Oklahoma would not receive over \$20 million in projected tax revenue, at least 250 temporary jobs and ten to twelve permanent jobs would not be generated, the surface owners would not receive payments from the wind farm operators, and enough electricity to power 50,000 homes would not be generated. ${ }^{129}$

Oklahoma has statutorily addressed the conflicts between wind farm operators and oil and gas producers. Oklahoma's Exploration Rights Act of 2011 states:

[T] he lessee of a wind or solar energy agreement or the wind energy developer shall not unreasonably interfere with the mineral owner's right to make reasonable use of the surface estate, including the right of ingress and egress therefor, for the purpose of exploring, severing, capturing and producing the minerals. ${ }^{130}$

This statute mirrors the rights existing under Oklahoma common law and does not increase or decrease the historical rights of the mineral estate owners and lessees. ${ }^{131}$ Additionally, the Oklahoma Legislature has stated

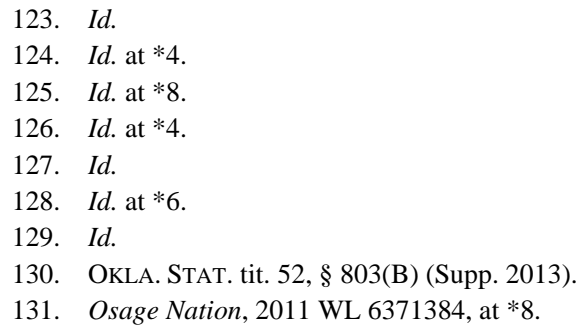


that "the development of wind energy resources is important to the economic growth of the state" and has encouraged the production of clean and renewable power. ${ }^{132}$

Under Oklahoma common law, the mineral estate owner or lessee is entitled to as much of the surface as is reasonably necessary to explore and develop the mineral estate "with due regard to the right of the owner of the surface." "133 In Gulf Pipe Line Co. v. Pawnee-Tulsa Petroleum Co., the oil and gas lessee attempted to sell the mineral lease to the landowners, a company involved in the collection and distribution of oil, at a "price much beyond its real value," which the landowners refused. ${ }^{134}$ The oil and gas lessee then "stood upon their naked right to drill where they pleased" and intended to drill several feet from a manifold pit, which allows inflammable and explosive gases to escape to avoid explosions. ${ }^{135}$ The oil and gas lessee had numerous less dangerous alternatives, but still "proposed to bore at this place of danger, unless the [landowner] would buy their lease at a price much greater than its value." 136 The Oklahoma Supreme Court held that if mineral lessees can "fully enjoy their own rights without injury to others they should not be allowed, out of the spirit of wantonness or of blackmail, to jeopardize the property and lives of others exercising an equal right," a rationale very similar to that of Texas's accommodation doctrine. ${ }^{137}$

\section{E. The Accommodation Doctrine and the Dominant-Servient Relationship in Kansas}

Kansas presents a unique situation, different from Texas and Oklahoma, because a Kansas court has rejected the traditional dominantservient relationship for oil and gas lessees used in those jurisdictions, and Kansas courts have not explicitly adopted the accommodation doctrine. In Rostocil v. Phillips Petroleum Co., the Kansas Supreme Court stated that " $[t]$ he lessee, under an oil and gas lease, does not own a dominant easement." ${ }^{138}$ However, the court employed a rationale similar

\footnotetext{
132. OKLA. STAT. tit. 17, § 160.12 .

133. Thompson v. Andover Oil Co., 691 P.2d 77, 81-82 (Okla. Civ. App. 1984).

134. 127 P. 252, 252-53 (Okla. 1912).

135. Id. at 253.

136. Id.

137. Id. at 254; see supra Part II.D.1 (discussing the accommodation doctrine in Texas).

138. 502 P.2d 825, 826 (Kan. 1972) (emphasis added).
} 
to the accommodation doctrine to resolve the dispute in Rostocil, despite never expressly adopting or even mentioning the doctrine. ${ }^{139}$

In Rostocil, the initial 1940 oil and gas lease stated that "[w]hen requested by lessor, lessee shall bury his pipe lines below plow depth.”140 In 1953, the lessee received a right-of-way easement to transport oil from adjacent properties, and the trial court held that the right-of-way easement did not modify the duties of the lessee created by the initial lease. ${ }^{141}$ As required by the contract, the oil and gas lessee buried the pipelines below plow depth. ${ }^{142}$ The lessor decided to terrace the property and requested that the lessee lower the pipelines so that the pipelines would remain below plow depth, and the lessee refused. ${ }^{143}$ The lessor then reburied the pipelines and sued the lessee to recover the associated costs. ${ }^{144}$

The trial court ruled for the lessee and found, based on the reasoning of Potter v. Northern Natural Gas Co., that there was not a continuing obligation to bury the pipelines more than once. ${ }^{145}$ In Potter, the trial court found that a lease provision that stated the lessee would "bury all pipe laid upon said land to a sufficient depth so as not to interfere with the cultivation of the soil," did not carry a continuing obligation. ${ }^{146}$ However, the Kansas Supreme Court overruled the lower court and found that, while the Potter provision did not carry a continuing obligation, the provision in Rostocil did. ${ }^{147}$ The essential difference between the two provisions appears to be the phrase, "[w]hen requested by the lessor," contained in the lease in Rostocil but not the one in Potter, which the Rostocil court found implied a continuing obligation. ${ }^{148}$ The Potter lease, in contrast, required the lessee only to bury the pipeline once. $^{149}$

Unlike the "true" accommodation doctrine, which requires the mineral estate to accommodate existing uses of the surface if it has alternative means of developing the property, the best explanation of

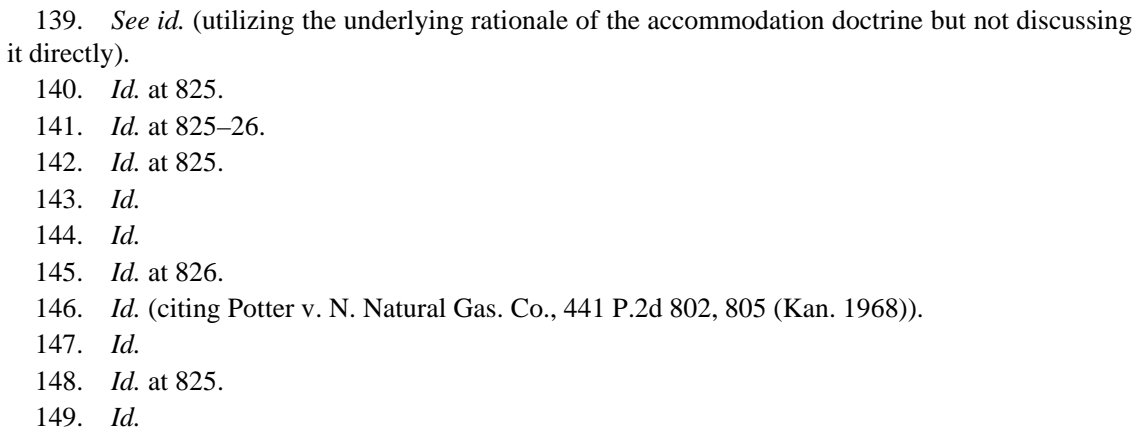


Rostocil is that the surface interest owners and the mineral lessee must accommodate each other and cannot interfere more than necessary with the other party's land use. ${ }^{150}$ However, as discussed below in Part III, the Rostocil opinion is not persuasive concerning the resolution of conflicts between wind farm operators and oil and gas producers.

\section{ANALYSIS}

Because Kansas lacks applicable common law or statutes, this Comment proposes a three-step approach, directed at three different groups, to resolve disputes between landowners, oil and gas developers, and wind farm operators. First, the Kansas Legislature should adopt a statute similar to the Oklahoma statute addressing the rights of wind farm operators. Second, Kansas courts should apply a modified form of the accommodation doctrine used in Texas that comports with wellestablished easement law and public policy concerns in Kansas. Third, landowners and potential easement holders should include provisions in their various conveyances expressing the rights granted to the lessor regarding surface use and the concurrent rights of other interest holders. These proactive steps will minimize future disputes and ensure that the rights of the various interest holders are clarified.

\section{A. Recommendation to the Kansas Legislature: Address the Potential Disputes Before Any Litigation Occurs}

The Kansas Legislature addressed wind farms in 2011 with the passage of section 58-2272 of the Kansas Statutes, but the Kansas Wind Farm Statute does not address the concurrent rights of other interest holders. ${ }^{151}$ Therefore, the Kansas Legislature should amend section 582272 to include the following provisions modeled from the existing language in the Kansas Wind Farm Statute and title 52, section 803 of the Oklahoma Statutes, or similar language to clarify the respective rights of the interest holders. ${ }^{152}$

58-2272. Instruments conveying interest involving wind or solar resources and technologies

\footnotetext{
150. Id. at 826 .

151. KAN. StAT. ANN. § 58-2272 (Supp. 2012).

152. See generally OKLA. STAT. tit. 52, § 803 (Supp. 2013). Some of the language in the recommended statutes is quoted directly from the Oklahoma statutes, but the Oklahoma statutes have been modified to apply to the wind energy industry and Kansas.
} 
(e) Unless specifically provided otherwise in an instrument transferring or retaining title to the mineral estate separate from the surface estate, the mineral owner has, and shall continue to have, the right to make reasonable use of the surface estate, including the right of ingress and egress therefor, for the purpose of exploring, severing, capturing and producing the minerals underlying the real property. ${ }^{153}$

(f) Unless specifically provided otherwise in an instrument granting a lease or easement involving wind resources and technologies to produce and generate electricity, the lessee or easement holder has, and shall continue to have, the right to make reasonable use of the surface estate, including the right of ingress and egress therefor, for the purpose of exploring, capturing and producing electricity on the real property.

(g) Notwithstanding any provision in a wind energy agreement or mineral estate lease, the lessee of a wind energy agreement or the wind energy developer shall not unreasonably interfere with the mineral owner or lessee's right to make reasonable use of the surface estate, and the oil and gas lessee or developer shall not unreasonably interfere with the wind lessee's right to make reasonable use of the surface estate. ${ }^{1}$

(h) At least thirty (30) days before entering upon the surface estate for the purposes of beginning construction of a wind energy facility, the wind energy developer shall provide written notice, by certified mail, of its intent to construct the wind energy facility to:

(1) Any operator who is conducting oil and gas operations upon all or any part of the surface estate and

(2) All lessees of oil and gas leases covering the mineral estate underlying any part of the surface estate that are filed of record with the county clerk in the county where the tracts are located and whose primary term has not expired.

The notice shall contain a map or plat of the proposed location of all of the various elements of the wind energy facility to be located on the surface estate. If the wind energy developer makes a search with reasonable diligence, and the whereabouts of a party entitled to any notice described in this subsection cannot be ascertained or such notice

153. The proposed subsection (e) is a version of OKLA. STAT. tit. 52, § 803(A), and certain parts of the original statute are omitted.

154. The proposed subsection (f) is a modified version of OKLA. STAT. tit. 52, § 803(A) with the language changed so that the statute applies to the wind energy industry.

155. The proposed subsection (g) is a modified version of OKLA. STAT. tit. 52, § 803(B) with the language changed to apply to the wind farm operator and the oil and gas producer. 
cannot be delivered, then an affidavit attesting to such diligent search for the parties shall be placed in the records of the county clerk where the surface estate is actually located. ${ }^{156}$

(i) The wind energy developer also shall publish notice of the intent to begin construction of a wind energy facility in one issue of a newspaper qualified to publish legal notices in the county where the wind energy facility is intended to be constructed, which notice shall be published at least thirty (30) days before entering upon the surface estate for the purpose of beginning construction of a wind energy facility and which notice shall include the legal description of the surface estate as to which the wind energy developer intends the construction of the wind energy facility. ${ }^{1}$

These proposed statutes are designed to clarify the rights of the various interest holders. Subsections (e) and (f) clarify that the mineral estate owner or the oil and gas lessee and the wind farm operator generally have the right to reasonably develop their estates, and that right can be altered by the conveyance granting the right, which is discussed in Part III.C. Subsection (g) is a codification of the modified accommodation doctrine discussed in Part III.B. Subsections (h) and (i) establish that wind farm operators must give notice to oil and gas developers of the construction of a wind farm on the land covered by the oil and gas lease and the general public in a newspaper. It is more appropriate to place this burden on the wind farm operators because oil and gas lessees have been in business significantly longer and are in some cases inherently unlikely to change, as opposed to the relatively young and flexible wind farm industry. The goal of subsections (h) and (i) is to prevent conflicts from occurring before construction begins. Additional language requiring oil and gas developers to give similar notice to wind farm lessees might also be appropriate.

\section{B. Recommendation to Kansas's Courts: Resolve Disputes Using a Modified Version of the Accommodation Doctrine}

\section{Rostocil v. Phillips Petroleum Co.: An Unpersuasive Opinion}

In Rostocil v. Phillips Petroleum Co., the Kansas Supreme Court stated that "[t]he lessee, under an oil and gas lease, does not own a

\footnotetext{
156. The proposed subsection (h) is a modified version of OKLA. STAT. tit. 52, § 803(C) with slight modifications and portions omitted.

157. The proposed subsection (i) is a modified version of OKLA. STAT. tit. 52, § 803(D) with the Oklahoma-specific language omitted.
} 
dominant easement." ${ }^{158}$ However, Rostocil is a questionable opinion for numerous reasons. First of all, Rostocil, a 1972 case, has never been cited by another Kansas case and has only been cited by one case in the entire country, which did so merely based on a specific provision of the lease in Rostocil. ${ }^{159}$ Furthermore, the short opinion is irrational and does not cite Kansas common law to reinforce the propositions it asserts. The opinion is two pages long and contains only one citation, to Potter $v$. Northern Natural Gas Co., but it is included as the basis of the trial court's decision, which was overturned. ${ }^{160}$

The opinion is irrational because it contains statements that are overly broad and unreasonable, such as the statement that an oil and gas lessee "is licensed to lay pipes whenever and wherever he finds it convenient." "161 This indicates that the lessee could lay the pipeline anywhere on the property, regardless of the damage it causes to the surface estate, as long as the location is convenient to the lessee. Based on Kansas common law and the accommodation doctrine adopted by other jurisdictions, that statement is inaccurate and unnecessary. ${ }^{162}$ The rights of the oil and gas lessee should be limited by the rights of other interest holders, and the oil and gas lessee does not have an absolute right to interfere with the existing rights and reservations of the surface owner and other interest holders.

The court held that the oil and gas lessee in Rostocil had an ongoing duty to bury pipelines below plow depth, even when the lessor and surface owner, the owner of the servient estate, terraced the property, which exposed the pipe and required the reburial of the pipelines. ${ }^{163}$ Under the common law of Kansas, the servient tenant may use the land covered by the easement in any manner that does not unreasonably interfere with the dominant tenant's use of the easement. ${ }^{164}$ Because the holding of Rostocil conflicts with this well-established rule regarding

\footnotetext{
158. 502 P.2d 825, 826 (Kan. 1972).

159. See Holly Creek Prod. Corp. v. Rose, No. 2009-CA-001971-MR, 2011 WL 557562, at *2 (Ky. Ct. App. Feb. 18, 2011). After citing Rostocil because of the similarity of its lease provision in question, the court in Rose instead followed a case that was more "persuasive." Id.

160. Rostocil, 502 P.2d at 826.

161. Id.

162. See supra Part II.D.1 (discussing the accommodation doctrine); see also S. Star Cent. Gas Pipeline, Inc. v. Cunning, 157 P.3d 1120, 1123 (Kan. Ct. App. 2007) (limiting the rights of the oil and gas producer based on an existing use by the surface owner).

163. Rostocil, 502 P.2d at 826 .

164. See Gilman v. Blocks, 235 P.3d 503, 514 (Kan. Ct. App. 2010) ("It is well settled that the owner of the servient tenement may use the land over which the way extends in any manner which does not [un]reasonably interfere with its use.” (alteration in original) (internal citation omitted)).
} 
easements, it is unclear whether Rostocil was decided based on a dominant-servient estate analysis or on the express terms of the oil and gas lease that required the lessee to "bury his pipe lines below plow depth" when requested by the lessor. ${ }^{165}$ The opinion's inconsistency with the common law suggests that the ruling was based on the express provisions of the lease, as opposed to a dominant-servient estate analysis. Consequently, the Rostocil opinion should not be read to make easement law and a dominant-servient analysis inapplicable to oil and gas leases in Kansas.

\section{Public Policy Factors}

Public policy also dictates that a form of the accommodation doctrine would be appropriate in Kansas. Kansas public policy strongly encourages the conservation of natural resources and considers the mutual interests of the lessor and lessee, instead of solely considering the lessee's interest in production. ${ }^{166}$ Implied covenants fill gaps in incomplete contracts, promote fairness between the parties, and serve this public policy. ${ }^{167}$ The implied covenant to reasonably develop oil and gas leases was enacted "[a]s a matter of Kansas public policy." 168 Over time, the emphasis of Kansas public policy has shifted from production to conservation of natural resources. ${ }^{169}$ Courts have responded to this shift by considering the mutual interests of the lessor and the lessee, as opposed to the sole interest in production of the lessee. ${ }^{170}$ Additionally, "[t]he production of natural gas in the state of Kansas in such manner and under such conditions and for such purposes as to constitute waste is ... prohibited." ${ }^{\prime 71}$ Waste includes economic waste, underground waste, and surface waste. ${ }^{172}$

It is in the best interest of Kansas to encourage both the wind energy and oil and gas industries to pursue as many opportunities within the state as possible. Obviously, both industries provide necessary energy and create economic benefits in the forms of jobs, tax dollars, and other

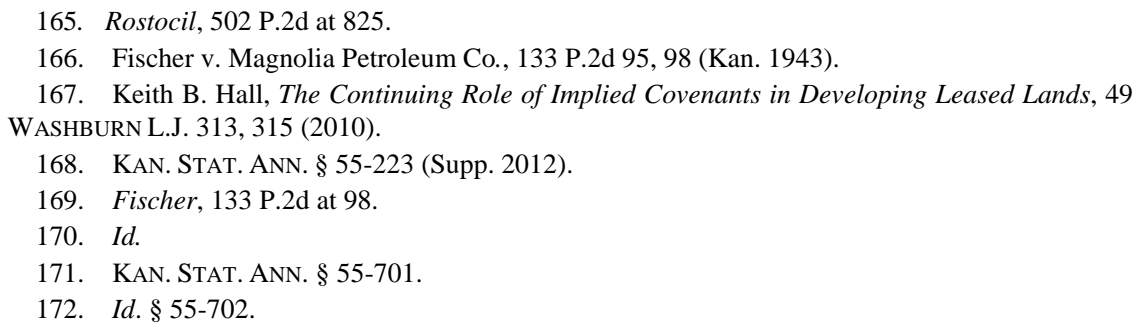


incidental benefits. ${ }^{173}$ To maximize these benefits, Kansas statutory and common law should define the rights of the various interest holders, encourage business, and clarify any ambiguities created by decisions such as Rostocil.

When companies have invested significant time and money to build facilities or select locations, those investments should be given priority, if at all possible, to avoid waste and frustration of businesses that provide important economic benefits to the state. Economic waste, which violates Kansas public policy, would occur if planning and construction endeavors had to be significantly modified or abandoned. The mineral estate can be fully developed from multiple surface locations with or without directional drilling, but the wind farm can only maximize energy production and economic benefits by placing wind turbines in carefully selected and optimized surface locations. Kansas public policy should resolve the conflict to maximize the economic and environmental benefits to the state and the parties involved in the conflict.

To maximize the potential benefits to the state, it is important for Kansas courts and the Kansas Legislature to encourage the various interest holders to accommodate each other. Thus, if the wind farm operator has claimed a location, the oil and gas producer should be required to accommodate that declaration and use other alternatives, such as directional drilling, to develop the mineral estate. Likewise, if the oil and gas producer has claimed a location, the wind farm operator should be required to use other alternatives, such as moving turbines and other infrastructure locations. Finally, in the event that both parties have invested time and money in selecting a location or constructing equipment that creates a conflict, the two should be required to resolve their dispute amicably and split the costs associated with resolution. This modified version of the accommodation doctrine, discussed in Part III.B.3, would prevent creating a preference for a particular industry and discouragement of another industry, which could discourage further business coming to the state.

Kansas courts might also balance the interests of the surface owner, oil and gas lessee, and the wind lessee using the rationales in Southern Star Central Gas Pipeline, Inc. v. Cunning ${ }^{174}$ and Brown v. ConocoPhillips Pipeline Co. ${ }^{175}$ In Cunning, an injunction would have

173. See supra Part II.B (discussing the benefits that the wind energy and oil and gas industries bring to Kansas).

174. 157 P.3d 1120 (Kan. Ct. App. 2007).

175. 271 P.3d 1269 (Kan. Ct. App. 2012). 
required moving a garage at a cost of around $\$ 20,000$ and therefore the Kansas Court of Appeals denied the injunction. ${ }^{176}$ In Brown, however, the Kansas Court of Appeals ordered the removal of the less-expensive and less-critical tree, which suggests that the value and material nature of the existing use is a factor. ${ }^{177}$ As an obstruction becomes less expensive to remove, as the location of the obstruction becomes less important, or as the potential for damage to the property or equipment increases, the likelihood that a court would require the obstruction to be moved also increases. Thus, requiring the oil and gas lessee or wind farm lessee to move significant equipment would be difficult to justify as long as the other lessee could still reasonably enjoy and benefit from the property.

Regardless of which party is required to move or adjust their plans, neither the wind or oil and gas industry nor landowners should be severely disadvantaged by Kansas statutory or common law. Wind farms provide direct economic benefits to the state, including millions of dollars brought into the state, jobs, and clean energy. ${ }^{178}$ Wind farms also provide indirect benefits to the surrounding community and industries by increasing the demand for goods and services. ${ }^{179}$ Oil and gas ventures provide similar benefits to the state. ${ }^{180}$ Kansas would not benefit economically by discouraging either party from doing business in Kansas, which should encourage the Kansas Legislature and Kansas courts to accommodate both parties as much as possible.

\section{A Proposal for a Modified Version of the Accommodation Doctrine in Kansas}

In Texas, the accommodation doctrine dictates that (1) if there is an existing use by the surface owner that would be substantially impaired and (2) there is an alternative industry practice available to produce the minerals, then "the rules of reasonable usage of the surface may require" the mineral estate owner to use the available alternative. ${ }^{181}$ If the oil and

\footnotetext{
176. 157 P.3d at $1122-23$.

177. $271 \mathrm{P} .3 \mathrm{~d}$ at 1277.

178. See supra Part II.B (discussing the economic benefits provided to Kansas by the wind energy industry).

179. E. Lantz, Nat'L Renewable Energy Lab., Economic Development BenEFits in NEBRASKA: A REPORT FOR THE NEBRASKA ENERGY OFFICE 5 (June 2009), http://www.nrel.gov /docs/fy09osti/44344.pdf.

180. See supra Part II.B (discussing the potential economic benefits provided to Kansas by the oil and gas industry operations in southern Kansas).

181. Haupt, Inc. v. Tarrant Cnty. Water Control \& Improvement Dist. No. One, 870 S.W.2d 350, 353 (Tex. Ct. App. 1994) (emphasis added); Diffen, supra note 4, at 246.
} 
gas producer does not have a reasonable alternative, the oil and gas producer may interfere with the surface owner's use of the property. ${ }^{182}$ This rationale could be altered slightly and adopted by Kansas courts to resolve disputes between surface owners, oil and gas developers, and wind farm operators. The questionable statement in Rostocil that "[t]he lessee, under an oil and gas lease, does not own a dominant easement" could be interpreted to remove the preferential treatment given to the mineral estate by Texas's accommodation doctrine and basically level the field among the various interest holders. ${ }^{183}$

Thus, the modified version of the accommodation doctrine would apply equally to all the interest holders and would establish that (1) if there is an existing use of the surface by the surface owner, wind farm operator, oil and gas developer, or other lessee that would be substantially impaired, and (2) there is an alternative industry practice available to develop the precluded estate, then the rules of reasonable use of the surface would require the precluded estate to use those alternative means. This concept also comports with Kansas common law regarding specific easements. ${ }^{184}$

If no alternative industry practice exists, the courts could turn to the public policy factors outlined above in Part III.B.2 to minimize the environmental and economic harm to the interest holders and the state. For example, if the oil and gas producer wanted to drill at a particular location and had no reasonable alternatives, but a wind turbine already existed at that location, then the wind farm would not be required to move the turbine due to the great expense and inconvenience of doing so. However, if only subsurface infrastructure belonging to the wind farm operator existed at that location, then the wind farm operator could be required to move the less expensive equipment to another location to allow the drilling, possibly at the expense of the oil and gas producer.

With the increasing availability and use of directional drilling, it is more likely that an alternative would be available to the oil and gas developer. ${ }^{185}$ The wind farm operator can develop the wind estate from numerous surface locations, as well. The energy output might not be optimal in all locations, but a slight decrease would still allow for reasonable development. Thus, this proposal is logically designed to

\footnotetext{
182. Haupt, 870 S.W.2d at 353 (quoting Tarrant Cnty. Water Control \& Improvement Dist. No. One v. Haupt, Inc., 854 S.W.2d 909, 911 (Tex. 1993)).

183. See supra Part III.B.1 (discussing Rostocil v. Phillips Petroleum Co., 502 P.2d 825 (Kan. 1972)).

184. See supra Part II.C.3-4 (discussing leases and easements in Kansas).

185. See supra Part II.D.1 (discussing the accommodation doctrine in Texas).
} 
conserve the energy and resources of the parties and promote the environmental and economic public policy concerns of the state.

\section{Recommendation to Landowners and Potential Lessees}

1. Oil and Gas Leases, Wind Farm Leases, and Cooperation Agreements Should Contain Provisions Clarifying the Concurrent Rights of Other Interest Holders

The express provisions of their respective agreements bind all surface owners, oil and gas producers, and wind farm operators. Oil and gas leases, as well as wind farm leases, "are contractual in nature and the general rules of contract law and interpretation apply to them." "186 The first step to determine which interest holder has superior surface rights should always be to examine the conveyances granting the leases or easements, as well as any agreements between the two lessees. When a contract is not ambiguous, the function of the court is to enforce the contract as made by the parties. ${ }^{187}$ In general:

The granting clause of the oil and gas lease, which is usually the first numbered paragraph of most lease forms, describes the purpose for which the lease is given and the extent of most rights and privileges given to the lessee by the landowner. Included among these rights are the right to explore, to mine and operate for and produce oil and gas, casinghead gas and casinghead gasoline, to lay pipelines, build tanks, power stations, telephone lines, to store oil on the leased premises, and to produce, save, take care of and manufacture such substances. ${ }^{188}$

Additionally, a party, such as a landowner, cannot contractually "create in others a privilege which he did not have." 189 Therefore, once the surface owner grants a specific easement to a lessee, the surface owner is servient to the dominant easement holder and cannot be allowed to subsequently grant another specific easement and create another dominant easement because the surface owner did not have a dominant privilege at that point in time. For example, a rural surface owner executes an oil and gas lease and the lessee reserves a specific area to drill an oil well; then the surface owner executes a wind farm lease and

\footnotetext{
186. Thoroughbred Assocs. v. Kan. City Royalty Co., 248 P.3d 758, 767 (Kan. Ct. App. 2011).

187. D.R. Lauck Oil Co. v. Breitenbach, 893 P.2d 286, 288 (Kan. Ct. App. 1995).

188. Bernard E. Nordling, Landowners' Viewpoints in Pipeline Right-Of-Way and Oil and Gas Lease Negotiations, J. KAN. B. A’ssN, Spring 1983, at 35.

189. Brooks v. Mull, 78 P.2d 879, 883 (Kan. 1938).
} 
the wind farm developer reserves the same location. In that scenario, assuming the latter interest would be a material interference with the original easement, the surface owner could not grant the second specific easement over the same area because the surface owner did not have the right to use that area to the exclusion of the oil and gas lessee. Because the surface owner did not have that right, the surface owner could not grant that right to the wind farm lessee. But the surface owner or other interest holder could use the property covered by the original specific easement as long as any subsequent use was not a material interference with the easement.

The express covenants of a lease can limit the locations available to the lessee, and agreements between the lessees themselves can designate locations available or not available to each lessee. The well locations are troublesome, particularly in southwest Kansas, because oil and gas leases executed thirty to fifty years ago cover thousands of acres. ${ }^{190}$ Under most of these older oil and gas leases, the surface owner "has no right to dictate the location of the well site or when the well should be drilled."191 In other words, the surface owner usually cannot tell the oil and gas developer where the developer must drill on the property. Customarily, the oil and gas lessee reimburses the surface owner for damages from well placement, such as lost crop production. ${ }^{192}$ Ideally, the lessee and surface owner cooperate to arrive at a mutually beneficial solution, but that is not always possible. ${ }^{193}$

Wind leases or agreements should contain provisions protecting the location of turbines and wind facility infrastructure and also limit the location of obstructions blocking the wind turbines. ${ }^{194}$ If the lease or agreement is unambiguous, the terms of the lease or agreement will be enforced as a contract. ${ }^{195}$ If the oil and gas lease or the wind lease states that wells or turbines cannot be within a certain distance of buildings or even located in a certain area, those terms will be enforced as a contract. As is the case with the agreements that the two parties have entered into

\footnotetext{
190. Nordling, supra note 188 , at 35.

191. Id. (citations omitted).

192. Id.

193. Id

194. Diffen, supra note 4, at 251; see also Charles L. Black \& Diann Waddill, Wind Energy Development in Texas: From Where the Wind Blows (A Local Perspective) (Feb. 26-27, 2007) (presented at the Wind Energy Institute), http://www.utcle.org/eLibrary/preview.php?asset_file_id $=10320$. For a discussion of drafting a wind lease, see Roderick E. Wetsel et al., Emerging Issues in Texas Wind Energy Law: Leases, Tax Abatements, and Ownership of Wind Rights, OIL, GAS \& ENERGY RESOURCES SEC. REP., March 2004, http://www.wetsel-carmichael.com/library.html.

195. D.R. Lauck Oil Co. v. Breitenbach, 893 P.2d 286, 288 (Kan. Ct. App. 1995).
} 
with the surface or mineral owner, the wind farm operator and oil and gas developer can also enter into agreements that better define each of the parties' rights through contract. ${ }^{196}$

Given that the Kansas Legislature has not yet addressed the issue and the unpredictability of courts in general, contract law provides the most immediate and concrete solution to determine which interest holder has priority. Future leaseholders should try to include provisions in the lease and cooperation agreements with other leaseholders that clarify the surface rights of each party and address how disputes will be resolved. These provisions should work to the benefit of all parties involved as much as possible to avoid economic waste and litigation. However, the interpretation of existing leases is complicated by the sheer amount of hypothetical scenarios.

\section{Analysis of Three Hypothetical Scenarios}

The first hypothetical occurs when either the wind farm operator or oil and gas developer has a specific easement ${ }^{197}$ on the surface property. The specific easement holder is the dominant tenant, and the surface owner and other interest holders, such as another lessee, do not have the right to materially interfere with the area covered by the specific easement. ${ }^{198}$ Although the specific easement holder in this situation has priority over the other interest holders to use the area as designated by the conveyance, the other interest holders can still utilize the area covered by the easement in any manner that is not a material interference with the specific easement holder or prohibited by contract. ${ }^{199}$

The second scenario occurs when both leaseholders were granted blanket easements, but neither the oil and gas developer, nor the wind farm operator, nor the surface owner has established an existing use at a specific location on the surface. In this case, the lessees have not established a priority based on a specific easement. Thus, the first party to gain a specific easement or use the surface would establish priority. However, the modified accommodation doctrine proposed in Part III.B.3

\footnotetext{
196. See id. ("Oil and gas leases are subject to the well-recognized rules of contract construction.”).

197. See supra Part II.C.4 (discussing specific and blanket easements).

198. See Aladdin Petroleum Corp. v. Gold Crown Props., Inc., 561 P.2d 818, 822 (Kan. 1977) (stating that an easement holder is generally the dominant tenant); Smith v. Harris, 311 P.2d 325, 336 (Kan. 1957) (discussing the requirement that the interference by another interest holder be material).

199. See Smith, 311 P.2d at 334; supra Part III.C.1 (discussing the use by a noneasement holder of an area covered by an easement).
} 
would dictate that if an existing use anywhere on the surface would be substantially impaired and the interfering interest holder has an alternative industry practice available to develop its estate, then the interfering estate would be forced to accommodate the existing use and utilize those alternative practices. ${ }^{200}$ The oil and gas producers could utilize directional drilling, the wind farm operator could adjust turbine locations, and all parties could adjust the location of infrastructure where the exact position of the equipment is less essential. ${ }^{201}$ In the less likely event that an alternative industry practice were unavailable, then public policy factors and agreements between the parties could be used to resolve the dispute. ${ }^{202}$

The third scenario occurs when both leaseholders were granted blanket easements and neither leaseholder has established an existing use of the surface, but multiple parties want to use the same location for developing their estates. This is a more complicated and speculative problem than the other scenarios and has a number of potential resolutions. The interest holders could create priority by racing to create a specific easement with the landowner or establishing an existing use that would cause the modified accommodation doctrine to govern the dispute. ${ }^{203}$ The interest holders could resolve the dispute contractually using a cooperation agreement and possibly share the costs associated with adjusting the developments. ${ }^{204}$ Otherwise, courts could use public policy factors to minimize the economic harm to the interest holders and the state. ${ }^{205}$

These hypothetical cases are just general examples of how the concepts outlined in this Comment could be used to resolve disputes in Kansas. Obviously, numerous other examples exist-many with increasingly complex issues that are outside the scope of this Comment. However, the discussion of these concepts and examples may provide guidance in identifying and resolving those more complex situations.

\footnotetext{
200. See supra Part III.B.3.

201. See supra Part II.D.1 (discussing reasonable alternatives such as directional drilling).

202. See supra Part III.B.3, III.C.1.

203. See supra Part II.C.4, III.B.3 (discussing specific easements and explaining the modified accommodation doctrine proposed by this Comment).

204. See supra Part III.C.1.

205. See supra Part III.B.3.
} 


\section{CONCLUSION}

Kansas has recently seen significant growth in the wind energy industry and has massive potential for continued growth, but the industry has grown so fast that the law has yet to catch up with it. There is a critical gap in the statutory and common law of Kansas that needs to be addressed by all parties involved, including legislators, judges, lawyers, landowners, and potential lessees. This Comment proposes a three-step approach to resolve the potential disputes between surface owners, oil and gas developers, and wind farm operators.

First, the Kansas Legislature should amend the Kansas Wind Farm Statute to include provisions that clarify that the oil and gas developer and wind farm operator have the right to reasonable use of the surface and that requires the wind farm operator to give notice of construction to the affected oil and gas developer, among others. Additionally, Kansas should adopt a modified version of the accommodation doctrine used in Texas and factor in public policy concerns to resolve disputes between the various interest holders. This modified version of the accommodation doctrine would require the interest holder to use available alternative means of developing the interest holder's estate if the proposed practice would interfere with an existing use of the surface by another interest holder. Finally, the conveyance granting an oil and gas lease or wind farm lease should contain provisions outlining the lessee's right to reasonable use of the surface and the rights of the respective interest holders. Even if the Kansas Legislature and Kansas courts do not follow the recommendations of this Comment, the parties themselves can contractually prepare for, and even resolve, disputes.

The proactive approach advocated by this Comment might prevent or limit future disputes between oil and gas producers, wind farm operators, and surface owners. The concepts outlined in this Comment can be used not only to resolve disputes after they have occurred, but also to identify existing and more complex issues that need attention in the Kansas Legislature, in Kansas courts, and between the interest holders. 